\title{
Evaluation of antibiotics, antibacterial chemicals and bio-agents against citrus canker caused by Xanthomonas axonopodis pv. citri (Hasse)
}

NAGARAJ BADIGER*, S.T. YENJERAPPA, M.N. NAIK, M.B. PATIL AND M. G. PATIL

Department of Plant Pathology, University of Agricultural Sciences, DHARWAD (KARNATAKA) INDIA

\section{ARITCLE INFO \\ Received : 13.08 .2016 \\ Revised : 08.09 .2016 \\ Accepted : 22.09 .2016}

KEY WORDS :

Canker, Antibiotics, Antibacterial chemicals, Bio-agents

*Corresponding author:

Email : badigernagaraj@gmail.com; yenjerappa@yahoo.co.in

\begin{abstract}
Six antibiotics, two antibacterial chemicals and five bio-agents were evaluated by in vitro against Xanthomonas axonopodis pv. citri (Hasse). Among the different antibiotics and antibacterial chemicals, Streptocycline $(10.84 \mathrm{~mm})$ and copper oxychloride (7.50 $\mathrm{mm}$ ) showed maximum inhibition zone followed by $\mathrm{K}$ cycline $(9.68 \mathrm{~mm})$. Among the bio-agents, Bacillus subtilis was effective with the inhibition zone of $(16.16 \mathrm{~mm})$ followed by Pseudomonas fluorescens (14.63 mm). The fungal bio control agents viz., Trichoderma viride and Trichoderma harzianum were found totally in effective against the pathogen.

How to view point the article : Badiger, Nagaraj, Yenjerappa, S.T., Naik, M.N., Patil, M.B. and Patil, M.G. (2016). Evaluation of antibiotics, antibacterial chemicals and bio-agents against citrus canker caused by Xanthomonas axonopodis pv. citri (Hasse). Internat. J. Plant Protec., 9(2) : 566-569, DOI : 10.15740/HAS/IJPP/9.2/566-569.
\end{abstract}

